\title{
Mini-incision open appendectomy versus laparoscopic appendectomy: An experience in a rural hospital
}

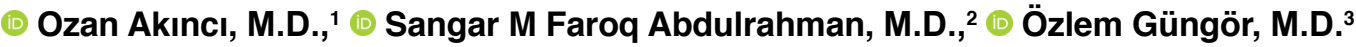

\author{
${ }^{1}$ Department of General Surgery, Hakkari State Hospital, Hakkari-Turkey \\ ${ }^{2}$ Department of General Surgery, İstanbul University-Cerrahpaşa, Cerrahpaşa Faculty of Medicine, İstanbul-Turkey \\ ${ }^{3}$ Department of Radiology, Hakkari State Hospital, Hakkari-Turkey
}

\begin{abstract}
BACKGROUND: There is still no consensus about whether laparoscopic appendectomy should be performed in selected cases or routinely in all cases for treatment of acute appendicitis. Especially for rural hospitals with laparoscopic equipment shortages, it is critical to develop surgical methods alternative to LA. This prospective study aimed to compare mini-incision open appendectomy (MOA) and laparoscopic appendectomy (LA) procedures.
\end{abstract}

METHODS: A total of 102 patients who had been operated on by a single surgeon for acute appendicitis between July 2018 and February 2020 and whose body mass index (BMI) was $<30$ were included in this study. Fifty-one patients were operated on with MOA and $5 \mathrm{I}$ with LA technique. The patients were evaluated concerning operation time, postoperative pain, hospital stay, postoperative infectious complications and cost-effectiveness.

RESULTS: Operation time was shorter in the MOA group than LA group $(p<0.001)$. VAS scores at postoperative $12^{\text {th }}$ and $24^{\text {th }}$ hours were significantly lower in the MOA group than those in the LA group $(p<0.001)$. Total hospitalization costs were lower in the MOA group than those in the LA group $(p<0.00 \mathrm{I})$. No significant difference was found between the two groups concerning length of hospital stay and postoperative infectious complications $(p=0.061$ and $p>0.999$, respectively).

CONCLUSION: Mini-incision open appendectomy is a reliable method in patients with acute appendicitis who have a BMI of $<30$ and it is superior to laparoscopic appendectomy concerning the operation time, postoperative pain and cost.

Keywords: Acute appendicitis; laparoscopic appendectomy; mini-incision open appendectomy.

\section{INTRODUCTION}

Acute appendicitis is one of the most commonly performed surgical procedures in the world with a lifetime incidence between 7-9\%. ${ }^{[1]}$ Open appendectomy (OA) was standardized and preferred by surgeons for nearly a hundred years after it was presented by McBurney ${ }^{[2]}$ for the first in 1894. Laparoscopic appendectomy (LA) was first described by Kurt Semm ${ }^{[3]}$ in 1983. Laparoscopic surgery has gained popularity and started to be applied in almost all surgical fields after results from laparoscopic cholecystectomy have been encouraging.
Although LA has advantages, such as shorter hospital stay and recovery time, earlier return to daily activities, less postoperative pain and infection rate, it also has some limitations, such as more intra-abdominal abscess formation, higher failure rate in complicated appendicitis and longer operation time in the hands of inexperienced surgeons. ${ }^{[4-10]}$ On the other hand, there are some studies reporting that mini-incision open appendectomy (MOA) is superior to LA in terms of small incision, operation time, hospital stay, return to daily activities, and cost. ${ }^{[11,12]}$ In addition to these facts, open appendectomy is still the preferred procedure in rural areas due to lack of laparoscopic experience and equipment.

\footnotetext{
Cite this article as: Akıncı O, Abdulrahman SMFA, Güngör Ö. Mini-incision open appendectomy versus laparoscopic appendectomy: An experience in a rural hospital. Ulus Travma Acil Cerrahi Derg 2021;27:310-314.

Address for correspondence: Ozan Akıncı, M.D.

Hakkari Devlet Hastanesi, Genel Cerrahi Kliniği, Hakkari, Turkey

Tel: +90438 - 21 I 6067 E-mail: ozanakinci1987@hotmail.com

Ulus Travma Acil Cerrahi Derg 2021;27(3):310-314 DOI: 10.14744/tjtes.2020.83023 Submitted: 14.03.2020 Accepted: 14.04.2020

Copyright 2021 Turkish Association of Trauma and Emergency Surgery
} 
For the reasons mentioned above, there is no consensus in the literature regarding which procedure should be used routinely for the treatment of acute appendicitis. With this background in mind, this prospective study aimed to compare operation time, postoperative pain level, hospital stay, postoperative morbidity and cost-effectiveness between the two procedures.

\section{MATERIALS AND METHODS}

This prospective study included 102 patients who were diagnosed with acute appendicitis, had a body mass index (BMI) of $<30$, and were operated on by a single surgeon between July 2018 and February 2020 in the General Surgery Clinic at Hakkari State Hospital in Turkey. Pregnant women, patients under the age of 18 , patients with a $\mathrm{BMI}>30$, patients with a previous history of abdominal surgery were excluded from this study. Ethics committee approval was received for this study. The patients were informed about the risks and benefits, and their informed consent was obtained. All of the patients in this study were operated on under general anesthesia and $5 \mathrm{I}$ patients were operated on with a laparoscopic appendectomy procedure (LA group), and 5 I patients were operated on with a mini-incision open appendectomy procedure (MOA group). The patients were randomized as one laparoscopic and one mini-incision open appendectomy in sequential order.

The mini-incision was defined as a McBurney incision of 2 to $3.5 \mathrm{~cm}$. The LA procedures were performed with the three-trocar technique. A $10-\mathrm{mm}$ port was placed under the umbilicus for the scope, a 5-mm port was placed in the left lower quadrant, and another 5-mm port was placed in the suprapubic area. The mesoappendix was transected with an ultrasonic energy device, and the appendix root was ligated with an endo-loop (EndoLoop, Vicryl Coated Ligature, Ethicon UK Ltd., Edinburgh, United Kingdom). The appendectomy was completed with endo-scissors. The specimen was placed in a sterile glove and removed from the abdomen through the 10 -mm port. All appendectomy specimens were sent for histopathological evaluation.

A prophylactic, single-dose, first-generation cephalosporin was administered to all patients. In all cases, a non-steroid anti-inflammatory agent was administered for postoperative analgesia every eight hours for the first 24 hours. Post-operative pain was measured by the visual analog scale (VAS) from 0 (no pain) to 10 (severe pain). For both surgical techniques, the cases were analyzed regarding the age, sex, American Society of Anaesthesiologists (ASA) score, BMI, the operation time, the length of hospital stay, VAS score at postoperative $12^{\text {th }}$ and $24^{\text {th }}$ hours, postoperative complications and cost-effectiveness. The patients were followed up for four weeks postoperatively.

Chi-square test, Fisher's test and Mann-Whitney $U$ test were used to compare the groups in the present study. The statistical significance level was set as $\mathrm{p}<0.05$ for all analyses. All statistical analyses were performed using SPSS version 20 (IBM Inc., Chicago, USA).

\section{RESULTS}

The median ages, in years, of the patients in group LA and group MOA were 31 and 30 , respectively. The female/male ratios were 18/33 and 16/35 in LA and MOA groups, respectively. ASA score-I and ASA score-2 patients ratios in the LA and MOA groups were $43 / 41$ and $8 / 10$, respectively. The median BMI was 24.9 in the LA group and 24.5 in the MOA group. The two groups had similar distributions regarding age, gender, BMI, and ASA score $(p=0.382, p=0.525, p=0.112$ and $p=0.109$, respectively). The demographic characteristics of the patients are shown in Table $I$.

There was perforated appendicitis in eight patients, five in the LA group and three in the MOA group, and there was no significant difference in perforation distribution between the groups $(p=0.46 I)$. The median operation time was 34 and 17 minutes in the LA and MOA groups, respectively. The median postoperative VAS scores were 7.0 and 6.0 at the $12^{\text {th }}$ hour and 4.0 and 2.0 at the $24^{\text {th }}$ hour in the LA and MOA groups, respectively. In addition, the median decrease in VAS scores from postoperative $12^{\text {th }}$ to $24^{\text {th }}$ hours was 3.0 in the LA group, while it was 4.0 in the MOA group. The median duration of hospital stay was 1.5 days in both groups. When postoperative infectious complications were examined, the findings showed that three patients $(5.88 \%)$ in the LA group

Table I. The demographic characteristics of the patients by groups

\begin{tabular}{lccc}
\hline & LA $(\mathbf{n}=51)(\%)$ & MOA $(\mathbf{n}=51)(\%)$ & p value \\
\hline Age & $31(19-61)$ & $30(18-73)$ & $0.382^{\mathrm{a}}$ \\
Gender (female/male) & $18 / 33$ & $15 / 36$ & $0.525^{\mathrm{b}}$ \\
Body mass index & $24.9(20.8-29)$ & $24.5(19-29)$ & $0.109^{\mathrm{a}}$ \\
ASA score I & $43(84.3)$ & $41(80.3)$ & $0.112^{\mathrm{c}}$ \\
ASA score 2 & $8(15.6)$ & $10(19.6)$ & \\
\hline
\end{tabular}

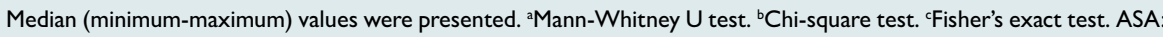
American Society of Anaesthesiologists; MOA: Mini-incision open appendectomy; LA: Laparoscopic appendectomy. 
Table 2. The comparison of clinical characteristics of the two groups

\begin{tabular}{|c|c|c|c|}
\hline & LA (\%) & MOA (\%) & p-value \\
\hline Operation time (min) & $34.0(8.0-55.0)$ & $17(9.0-35.0)$ & $<0.001^{\mathrm{a}}$ \\
\hline Hospital stay (day) & $1.50(1.0-7.0)$ & $1.50(1.0-5.0)$ & $0.991^{\mathrm{a}}$ \\
\hline VAS score at $12^{\text {th }}$ hour & $7.0(4.0-9.0)$ & $6.0(4.0-9.0)$ & $<0.001^{\mathrm{a}}$ \\
\hline VAS score at $24^{\text {th }}$ hour & $4.0(1.0-6.0)$ & $2.0(1.0-7.0)$ & $<0.001^{\mathrm{a}}$ \\
\hline Decrease in the VAS score & $3.0(1.0-5.0)$ & $4.0(0.0-7.0)$ & $<0.001^{a}$ \\
\hline Wound infection & $3(5.88)$ & $2(3.92)$ & $0.647^{b}$ \\
\hline Cost (USD) & 292.8 & 231.4 & $<0.00 I^{\mathrm{a}}$ \\
\hline
\end{tabular}

and two patients $(3.92 \%)$ in the MOA group developed a wound infection. None of the patients developed an intra-abdominal abscess. When total hospitalization costs were analyzed, the median cost was USD 292.8 in the LA group and USD 231.4 in the MOA group. The operation time, VAS scores at postoperative $12^{\text {th }}$ and $24^{\text {th }}$ hours, and total cost were significantly lower in the MOA group than those in the LA group $(p<0.001)$ (Table 2). There was no significant difference between the two groups concerning the length of hospital stay and postoperative infectious complications $(p=0.06 \mathrm{I}$ and $p>0.999$, respectively) (Table 2 ).

\section{DISCUSSION}

Appendectomy, the most common surgical procedure performed in general surgery, is still performed by both open and laparoscopic methods due to a lack of consensus about which is the most suitable method. McBurney's incision has been applied for many years, followed by several other incisions developed later, including Rutherford-Morrison, Rockey-Davis, Battle, and Lanz incision. With the discovery of laparoscopic surgery, many surgeons tended to perform LA rather than OA for the treatment of acute appendicitis. Meta-analyses have confirmed that LA is safe and results in a faster return to normal activities with fewer wound complications at the expense of longer operating times. ${ }^{[13,14]}$ In addition, LA has many advantages, such as lower postoperative pain, shorter hospital stay, high diagnostic accuracy, especially in women and elderly patients, better cosmetic results, less perioperative blood loss..$^{[5,7,15,16]}$ In addition to open and laparoscopic appendectomy techniques, the mini-incision open appendectomy technique has recently been used, too, as an alternative method in treating acute appendicitis. There are few studies in the literature similar to our study, comparing LA and MOA, which have reported that MOA procedure has advantages, such as a smaller incision, shorter operation time, less postoperative pain, and fewer infectious complications. ${ }^{[11,12,17,18]}$

In the literature, it has been shown in many studies that the operation time of LA is longer than OA. ${ }^{[4,5,13,19]}$ Some authors have reported that the operation time of MOA is significantly shorter than LA. ${ }^{[1,18]}$ On the other hand, Çiftçi et al. ${ }^{[20]}$ have concluded in a prospective study that there is no significant difference between MOA and LA concerning operation time. In our study, we found that the operation time in MOA was significantly shorter than that in LA. Thick fatty tissue negatively effects operation time especially in obese patients. To minimize this adverse effect and make the condition equal for both groups, we only included patients with $\mathrm{BMI}<30$ in our study. We believe that this selectivity has an important effect on MOA procedures' shorter operation time than LA.

One of the most well-known advantages of LA is shorter hospital stay. The duration of hospital stay is closely related to social standards, health-insurance systems, and hospital policies. Previous studies have shown that patients who underwent LA had shorter hospital stays. ${ }^{[5,6,16]}$ Bhasin et al. ${ }^{[18]}$ reported a shorter hospital stay in the MOA procedure, while Shah et al. ${ }^{\left[{ }^{\prime \prime}\right]}$ reported no significant difference between the LA and MOA. In our study, we found that there was no significant difference between the two groups concerning length of hospital stay.

Pain assessment varies depending on the individuals, geography and culture. To standardize pain assessment, we used a standard scale, the VAS score, and administered non-steroid analgesics every eight hours in the first 24 hours postoperatively. In this standardized procedure, we observed significantly less postoperative pain in the MOA group than the LA group. Similar to our study, some studies reported that MOA was superior to LA with less postoperative pain. ${ }^{[12,17,18]}$

The most common complications after appendectomy are wound infection, intra-abdominal abscess, and ileus. ${ }^{[15]}$ In the literature, several studies have reported that the LA procedure is superior to the OA procedure concerning wound infection and intra-abdominal abscess. ${ }^{[4,6,8,10,15]}$ In contrast, Sauerland et al. ${ }^{[14]}$ reported an increased incidence of abdominal abscess in LA. Shah et al. ${ }^{\left[{ }^{1 I}\right]}$ also reported that postoperative complications were less common in the MOA procedure. In 
our study, none of the patients developed an intra-abdominal abscess, and no significant difference was found between the two groups concerning wound infection.

The cost of laparoscopic equipment and resources increases the total cost of hospitalization. Accordingly, high costs lead to difficulties in access to laparoscopic equipment in countries with low socioeconomic status. In some other studies, the total cost of care was reported to be significantly higher for LA than both for OA and MOA. ${ }^{[7,11,12,14,21]}$ Similarly, we found that the MOA procedure was more cost-effective than the LA procedure. We think this is a critical issue to keep in mind for surgeons working in rural hospitals with equipment shortages.

Although our study is a prospective study, the limitations of our study are the low number of patients, being single-centered, not evaluating the postoperative cosmetic satisfaction of patients and the time to return to daily activities.

\section{Conclusion}

Mini-incision open appendectomy procedure is a reliable surgical method in acute appendicitis patients with a BMI of $<30$ and is superior to laparoscopic appendectomy concerning the operation time, postoperative pain, and cost. For general surgeons working under limited financial conditions, such as those working in rural hospitals, the MOA procedure can be safely applied in the treatment of acute appendicitis. However, randomized controlled trials involving larger patient groups are needed.

Acknowledgements: We would like to thank Prof Dr Vedat Durgun for his support in critical review.

Ethics Committee Approval: Ethics committee approval was received for this study from the institutional Ethics Committee of Van Yüzüncü Yıl University, Dursun Odabaş Medical Faculty (29.01.2020/04).

Peer-review: Internally peer-reviewed.

Authorship Contributions: Concept: O.A.; Design: O.A.; Supervision: O.A.; Materials: O.A., Ö.G.; Data: O.A., Ö.G., S.M.F.A.A.; Analysis: O.A., Ö.G., S.M.F.A.A.; Literature search: O.A., S.M.F.A.A.; Writing: O.A.; Critical revision: O.A.

Conflict of Interest: None declared.

Financial Disclosure: The authors declared that this study has received no financial support.

\section{REFERENCES}

1. Addiss DG, Shaffer N, Fowler BS, Tauxe RV. The epidemiology of appendicitis and appendectomy in the United States. Am J Epidemiol 1990;132:910-25. [CrossRef]
2. McBurney $\mathrm{C}$. The incision made in the abdominal wall in cases of appendicitis, with a description of a new method of operating. Ann Surg 1894;20:38-43. [CrossRef]

3. Semm K. Endoscopic appendectomy. Endoscopy 1983;15:59-64.

4. Tzovaras G, Baloyiannis I, Kouritas V, Symeonidis D, Spyridakis M, Poultsidi A, et al. Laparoscopic versus open appendectomy in men: A prospective randomized trial. Surg Endosc 2010;24:2987-92. [CrossRef]

5. Shaikh AR, Sangrasi AK, Shaikh GA. Clinical outcomes of laparoscopic versus open appendectomy. JSLS 2009;13:574-80. [CrossRef]

6. Oravsky M, Bak V, Schnorrer M. Laparoscopic versus open appendectomy in treatment of acute appendicitis. Bratisl Lek Listy 2014;115:660-6.

7. Özsan İ, Karabuğa T, Yoldaş Ö, Alpdoğan Ö, Aydın Ü. Laparoscopic appendectomy versus mini-incision appendectomy in patients with lower body mass index and noncomplicated appendicitis. Gastroenterol Res Pract 2014;2014:138648. [CrossRef]

8. Ward NT, Ramamoorthy SL, Chang DC, Parsons JK. Laparoscopic appendectomy is safer than open appendectomy in an elderly population. JSLS 2014;18:e2014.00322. [CrossRef]

9. Fahrner R, Schöb O. Laparoscopic appendectomy as a teaching procedure: Experiences with 1, 197 patients in a community hospital. Surg Today 2012;42:1165-9. [CrossRef]

10. Sakpal SV, Bindra SS, Chamberlain RS. Laparoscopic appendectomy conversion rates two decades later: An analysis of surgeon and patient-specific factors resulting in open conversion. J Surg Res 2012;176:42-9.

11. Shah B, Vaidhya N, Anchalia MM. Comparative study between laparoscopic appendicectomy and small incision open (mini lap) appendicectomy in cases of acute appendicitis. Int J Sci Res 2013;2:2319-64.

12. Kar WQ, Ahmed Z, Chowdhary M, Singh B. Mini incision appendectomy for acute uncomplicated appendicitis: An alternative to laparoscopic appendectomy. Int J Sci Res 2018;7:1701-3.

13. Garbutt JM, Soper NJ, Shannon WD, Botero A, Littenberg B. Meta-analysis of randomized controlled trials comparing laparoscopic and open appendectomy. Surg Laparosc Endosc 1999;9:17-26. [CrossRef]

14. Sauerland S, Lefering R, Holthausen U, Neugebauer EA. Laparoscopic vs conventional appendectomy-a meta-analysis of randomised controlled trials. Langenbecks Arch Surg 1998;383:289-95. [CrossRef]

15. Gurrado A, Faillace G, Bottero L, Frola C, Stefanini P, Piccinni G, et al. Laparoscopic appendectomies: Experience of a surgical unit. Minim Invasive Ther Allied Technol 2009;18:242-7. [CrossRef]

16. Shimoda M, Maruyama T, Nishida K, Suzuki K, Tago T, Shimazaki J, et al. Comparison of clinical outcome of laparoscopic versus open appendectomy, single center experience. Heliyon 2018;4:e00635. [CrossRef]

17. Sundaravadanan BS, Sudarshan PB, Prabu Shankar S. Mini incision appendectomy: An analysis of 70 cases. Int Surg J 2017;4:896-8. [CrossRef]

18. Bhasin SK, Dhar S. Mini-appendectomy (an experience of 100 cases).JK Pract 2005;12:11-3.

19. Li X, Zhang J, Sang L, Zhang W, Chu Z, Li X, et al. Laparoscopic versus conventional appendectomy-a meta-analysis of randomized controlled trials. BMC Gastroenterol 2010;10:129. [CrossRef]

20. Çiftçi F. Laparoscopic vs mini-incision open appendectomy. World J Gastrointest Surg 2015;7:267-72. [CrossRef]

21. Lee HJ, Park YH, Kim JI, Choi PW, Park JH, Heo TG, et al. Comparison of clinical outcomes and hospital cost between open appendectomy and laparoscopic appendectomy. J Korean Surg Soc 2011;81:321-5. [CrossRef] 
ORİJINAL ÇALIŞMA - ÖZET

\section{Laparoskopik apendektomiye karşı mini-insizyon açık apendektomi: Bir kirsal hastane deneyimi \\ Dr. Ozan Akıncı, ${ }^{1}$ Dr. Sangar M Faroq Abdulrahman, ${ }^{2}$ Dr. Özlem Güngör ${ }^{3}$}

${ }^{1}$ Hakkari Devlet Hastanesi, Genel Cerrahi Kliniği, Hakkari

2'̇stanbul Üniversitesi-Cerrahpaşa, Cerrahpaşa Tıp Fakültesi, Genel Cerrahi Anabilim Dalı, İstanbul

${ }^{3}$ Hakkari Devlet Hastanesi, Radyoloji Kliniği, Hakkari

AMAÇ: Akut apandisit tedavisinde laparoskopik apendektominin (LA) yalnızca seçilmiş olgularda mı yoksa her olguda rutin olarak mı uygulanması gerektiği konusunda henüz fikir birliği yoktur. Özellikle laparoskopik ekipman kısıtlılı̆̆ı olan kırsal bölge hastanelerinde LA'ya alternatif cerrahi tekniklerin geliştirilmesi önemlidir. Bu ileriye yönelik çalışma mini-insizyon açık apendektomi (MAA) ile laparoskopik apendektomi prosedürlerini karşılaştırmayı amaçlamaktadır.

GEREÇ VE YÖNTEM: Temmuz 20I8-Şubat 2020 tarihleri arasında tek cerrah tarafından akut apandisit nedeniyle ameliyat edilen ve vücut kitle indeksi (VKi) <30 olan 102 hasta çalışmaya dahil edildi. Hastaların 5I'’i MAA, 5 I'i ise LA tekniği ile ameliyat edildi. Hastalar hastanede yatış süresi, operasyon süresi, ameliyat sonrası ağrı, ameliyat sonrası morbidite ve maliyet açısından değerlendirildi.

BULGULAR: Operasyon süresi MAA grubunda LA grubuna göre daha kısa idi $(p<0.00 I)$. Ameliyat sonrası I2. ve 24 . saat VAS skorları MAA grubunda LA grubuna göre anlamlı derecede daha düşüktü $(p<0.00 \mathrm{I})$. MAA grubundaki hastaların toplam hastane maliyeti LA grubundan anlamlı derecede daha düşüktü $(p<0.00 \mathrm{I})$. Hastanede yatış süresi ve ameliyat sonrası enfeksiyöz komplikasyonlar açısından iki grup arasında anlamlı bir fark bulunmadı (sırasıyla, $p=0.061$ ve $p>0.999$ ).

TARTIŞMA: Mini-insizyon açık apendektomi akut apandisit tanıl, VKi <30 olan hastalarda güvenilir bir yöntem olup operasyon süresi, ameliyat sonrası ağrı ve maliyet yönünden laparoskopik apendektomiden üstündür.

Anahtar sözcükler: Akut apandisit; laparoskopik apendektomi; mini-insizyon açık apendektomi.

Ulus Travma Acil Cerrahi Derg 2021;27(3):310-314 doi: 10.14744/tjtes.2020.83023 